\title{
O SETOR PRIVADO DE ENSINO SUPERIOR NA AMÉRICA LATINA
}

\author{
EUNICE RIBEIRO DURHAM \\ HELENA SAMPAIO \\ Pesquisadoras do Núcleo de Pesquisas sobre Ensino Superior - Nupes - \\ da Universidade de São Paulo
}

\begin{abstract}
RESUMO
O artigo trata da relação entre o setor público e o privado em cinco sistemas nacionais de ensino superior: Argentina, Brasil, Chile, Colômbia e México. Em cada país constatam-se dinâmicas muito específicas da relação público/privado em seus respectivos sistemas de ensino superior. Em contraste com o Brasil, onde a expansão do setor privado iniciou-se em meados dos anos 60 e retraiu-se ao longo da década de 80 , nos demais países, o crescimento absoluto e relativo das matrículas no setor privado, além de mais recente, ainda não apresentou sinais de esgotamento. Diferenças de timing na expansão do setor privado nos cinco países suscitam questóes relevantes sobre a oportunidade da abertura do ensino superior para o mercado e sobre a relação do Estado com os respectivos sistemas nacionais, temas, sem dúvida, centrais no debate contemporâneo sobre ensino superior na América Latina.

ENSINOSUPERIOR-AMÉRICALATINA-ENSINOPARTICULAR-ENSINOPÚBLICO
\end{abstract}

\begin{abstract}
THEPRIVATESECTORIN LATINAMERICA: A COMPARATIVEANALYSIS. The article treats the relationship between the public and private sectors in five national systems of higher education: Argentina, Brazil, Chile, Colombia and Mexico. In each country there are very specific dynamics in the public/private relationship and their respective higher education systems. In contrast with Brazil where the expansion of the private sector began the mid 60s and contracted during the 80s, in the other countries the absolute and relative growth of enrollments in the private sector, in addition to being more recent, still shows no signs of exhaustion. Differences in timing in the expansion of the private sector in the five countries invite relevant questions about the opportunity for opening up higher education to the market and about the relationship with the State with the respective national systems. These issues doubtlessly are central in the contemporary debate on higher education in Latin America.
\end{abstract}

Trabalho apresentado na reunião do Grupo Latino-Americano de Estudos Comparados sobre Políticas do Ensino Superior na América Latina em Cuernavaca, México, em 1997. 


\section{INTRODUÇÃO}

sistema de ensino superior e, mais especificamente, a universidade, tem sido, na América Latina, tema de intenso debate político. Isso se deve, provavelmente, ao fato de as universidades terem sempre tido forte presença política na vida nacional e sido consideradas como o centro, por excelência, de formação das elites políticas progressistas dos diferentes países. Mais que isso, no passado, elas se tornaram, muitas vezes, pela ação do movimento estudantil, vanguarda de reformas políticas, sociais e culturais, consideradas necessárias para o desenvolvimento nacional, e guardiãs da democracia.

Por isso mesmo, o debate, até hoje, se trava em um campo eminentemente politizado. Embora o tema da universidade, sua autonomia, seu papel e sua função, mobilize, de forma permanente, a academia, só nos últimos anos tem dado origem a pesquisas acadêmicas. Esse crescente interesse pelos sistemas de ensino superior como área de investigação já produziu uma literatura razoavelmente vasta e um debate freqüente entre pesquisadores de diferentes países.

Um elemento central das análises recentes é o fenômeno da privatização, que está igualmente presente no debate ideológico. Nesse debate, o termo privatização tem sido usado para designar experiências muito distintas. Visto freqüentemente como resultado de uma conspiração neoliberal capitaneada pelo Banco Mundial, o termo privatização reúne, como aspectos de uma mesma realidade, ações e problemas muito diversos. No Brasil, por privatização entende-se tanto a cobrança de taxas e anuidades nas instituições públicas quanto a expansão das matrículas no setor privado (independentemente de um crescimento paralelo do setor público), todas as formas de análise e de propostas de controle de custos, assim como diferentes iniciativas de avaliação institucional. Todos esses aspectos são considerados, indistintamente, como demonstração do interesse governamental em reduzir seu investimento na educação, em geral, e na superior, em especial, e da adoção de uma lógica de mercado deletéria aos interesses mais elevados do ensino e da sua subordinação às exigências do capitalismo e da globalização do mercado.

Como mostram as pesquisas mais recentes, esses diferentes aspectos não estão necessariamente associados e se apresentam em diferentes versões conforme o país considerado. De fato, verifica-se um crescimento contínuo do setor privado no conjunto da América Latina. Contribuindo, em 1955, com apenas 14\% do total de matrículas no ensino superior, atingiu, em 1988, perto de 38\% (Balán, 1993a)'. Embora o setor público seja ainda dominante no conjunto da América Latina, o setor privado tem crescido de forma impressionante neste último meio século (Levy, 1986). Não há dúvida de que em diversos países o setor privado já responde pela maioria das matrículas de ensino superior e apre-

I. Ao apresentar os dados Balán observa que Levy (1992) considera exageradas as informações para 1988 fornecidas pelo Centro Regional para la Educación Superior en America Latina y el Caribe. 
senta um dinamismo que parece ameaçar a tradicional hegemonia das instituições estatais. O fenômeno merece análise mais objetiva. E, se as informações disponíveis não nos permitem prever uma situação de substituição do ensino superior público pelo privado, os dados apontam para uma alteração nas relações estruturais que sempre existiram entre esses dois setores.

A questão da interdependência entre o ensino superior público e privado é crucial para a compreensão da dinâmica da expansão dos sistemas em seu conjunto; de um lado, diante das reformas estruturais mais amplas que constam das agendas de governo dos países latino-americanos nas últimas décadas; de outro, em relação às políticas públicas referentes ao setor.

Para analisar o fenômeno, dados comparativos são importantes porque permitem identificar tendências estruturais na diversidade das situações conjunturais. Este trabalho trata da relação entre o setor público e o privado em cinco sistemas nacionais de ensino superior: Argentina, Brasil, Chile, Colômbia e México no período entre 1955 e 1995. A escolha desses países não foi aleatória. Deve-se, em primeiro lugar, à existência de séries estatísticas disponíveis. Em segundo lugar, porque nesses países, conforme a análise indica, desenvolveram-se padrões distintos de sistemas de ensino superior. Em todos eles, entretanto, a expansão do setor privado insere-se no processo mais geral de crescimento das matrículas globais de ensino superior. Esse crescimento ocorre, com exceção da Argentina, no período focalizado neste trabalho. Por outro lado, as diferenças de timing na expansão das matrículas públicas e privadas suscitam questões relevantes no tocante à abertura dos sistemas de ensino superior para o mercado e quanto à relação do Estado com os respectivos sistemas nacionais.

Com base na análise do desenvolvimento do setor privado de ensino superior na Argentina, Brasil, Chile, Colômbia e México, o estudo procura fornecer alguns subsídios para o encaminhamento dessas questões e contribuir, assim, para o debate sobre o fenômeno da privatização do ensino superior na América Latina.

As questões fundamentais referem-se ao timing da expansão do ensino superior, em geral, e do privado, em especial; à relação entre a expansão desses dois setores; à heterogeneidade do setor privado; às diferentes orientações imprimidas pelas políticas governamentais no tocante ao crescimento relativo dos dois setores e à natureza das interações que, em cada país, se estabelecem entre o ensino superior público e o privado.

\section{O CONTEXTO HISTÓRICO}

A expansão do setor privado que ocorreu nesta segunda metade do século deve ser compreendida no contexto da tradição universitária que foi característica da América Latina no período anterior. Especialmente importante, nessa tradição e na história dos sistemas de ensino superior, é o papel das universidades católicas. 
A análise pioneira feita por Levy (1986a) sobre as ondas de expansão do setor privado de ensino superior na América Latina distingue três momentos ou movimentos distintos. $\bigcirc$ primeiro diz respeito ao surgimento e/ou consolidação das universidades católicas; o segundo, às instituições privadas de elite e o terceiro, às instituiçõos privadas voltadas para a absorção da demanda de ensino superior em grande escala, que começa a se intensificar a partir de meados deste século.

Para se compreender a especificidade dessa última onda de privatização é preciso distingui-la do surgimento e/ou consolidação das universidades confessionais que se prendem a uma tradição mais antiga, a qual estabeleceu uma outra forma de relação com o Estado. Na verdade, e durante muito tempo, a Igreja Católica pretendeu deter o monopólio sobre o ensino superior, utilizando recursos públicos destinados a essa finalidade em estreita simbiose com o Estado.

Com efeito, na América Hispânica, a colonização foi acompanhada da criação muito precoce de universidades católicas, sustentadas pelo Estado, no modelo da contra-reforma espanhola. Em quase todos os países, a independência política das colônias foi acompanhada de um movimento de secularização que separou Igreja e Estado, transformando as universidades tradicionais em instituições públicas e seculares e modernizando-as.

Essa tendência não se implantou sem forte oposição da lgreja e os sistemas criados no século $X I X$ resultaram dessa luta, que teve desencadeamentos diferentes nos diversos países. No Chile, estabeleceu-se um sistema dual, formado de universidades públicas laicas e universidades católicas que recebiam do Estado o mesmo tipo de financiamento. $\mathrm{Na}$ Colômbia, a força da Igreja Católica logrou impedir a criação de uma universidade pública laica até meados deste século. No México e na Argentina, o sucesso da secularização foi completo, e as universidades católicas só foram recriadas, respectivamente, nas décadas de 40 e 50 do século $X X$, mas separadas do Estado.

Brasil seguiu um caminho diferente. A Coroa portuguesa impediu a criação de estabelecimentos de ensino superior de qualquer tipo. As primeiras instituições de ensino superior, criadas no século XIX, na ocasião da vinda da corte ( $8 \mid 2$ ), não foram universidades, mas seguiram o modelo napoleônico de faculdades ou escolas superiores autônomas, laicas e estatais (ainda que sob influência católica), voltadas para a formação de profissionais liberais. $\bigcirc$ confronto entre Estado e Igreja ocorreu muito mais tarde, na década de 30 deste século, no momento da criação das primeiras universidades no país (Schwartzman, Bomeny, Ribeiro, 1984). A corrente secular acabou predominando e a Igreja terminou por criar sua própria rede de universidades católicas, a partir da década de 40, com o apoio do Estado que financiou parcialmente, por muito tempo, essas instituições paralelas.

Em um sistema com essas características, não existe propriamente uma oposição entre os setores público e privado; instituições católicas e laicas são muito semelhantes em seus objetivos, em sua organização, na qualidade do ensino que ministram e, freqüentemente, até na dependência de recursos públicos. Identifica-se, assim, em um sistema com 
essas características um certo paralelismo entre instituições laicas estatais e católicas não estatais. Trata-se portanto de um setor privado muito especial.

Outro tipo de instituição é formado por aquelas que compõem a segunda onda apontada por Levy (1986a). São universidades ou estabelecimentos equivalentes, laicos, não estatais e de elite. $\bigcirc$ Instituto Tecnológico de Monterrey, no México, é um bom exemplo desse tipo. Em geral, essas instituições são seletivas e procuram formar pessoal altamente qualificado. Algumas delas chegam a contar com subsídios estatais, apoio empresarial ou de elites locais. No Brasil, a Escola de Administração de Empresas da Fundação Getúlio Vargas e o Instituto Universitário de Pesquisas do Rio de Janeiro pertencem a esse tipo, assim como no Chile, as três universidades laicas mais antigas, que são financiadas com recursos públicos.

Por fim, existem as instituições privadas criadas para a absorção da demanda de estudantes que não lograram ingressar nas universidades públicas ou nas instituições privadas mais seletivas. Essas instituiç̧̃̃es, que raramente se constituem como universidades, foram, em geral, criadas depois da década de 60 e concentram sua oferta de serviços docentes em carreiras de alta demanda e baixo custo de produção. Reconhecidamente funcionam, muitas vezes, como uma verdadeira "fábrica de títulos" (Levy, 1986). Com independência garantida por seu estatuto jurídico, um grupo considerável de instituições desse tipo atua no mercado com fins de lucro.

Com base nessas considerações, haveria que se dedicar maior atenção às instituições do terceiro tipo, porque sua criação altera a relação entre o setor público e o privado de ensino superior. Conforme observado anteriormente, a existência de instituições católicas não estatais representa uma diversificação muito pequena no sistema. As instituições privadas, laicas, de elite constituem uma minoria. $\bigcirc$ que caracteriza o terceiro tipo, que poderíamos denominar "empresarial", é o fato de estar voltado para o mercado e ser controlado por ele. Isso constitui o elemento novo nos sistemas latino-americanos. Inspirados na trilogia de Clark ( 1983) pode-se afirmar que, até o desenvolvimento de um mercado educacional, tal como conhecemos hoje, a Igreja, o Estado e a comunidade acadêmica, incluindo nesta o movimento estudantil, funcionavam como os três pólos de tensão que regulavam os sistemas. Do grau de tensão entre esses diferentes agentes originaram-se sistemas com configurações tão diferentes na América Latina.

Com o crescimento das instituições de atendimento da demanda de massa, a tensão que se estabelece é entre o mercado e o Estado. Como o setor empresarial não depende de financiamento público, o mercado parece ter tido mais êxito no controle do sistema, em que pese algumas tentativas de controle, em geral frustradas, por parte do Estado.

A predominância do mercado no controle desse novo segmento do setor privado é fundamental para entender a batalha ideológica que se trava, em muitos países, em torno da chamada privatização. É preciso ter em conta que a orientação para o mercado está 
associada à perda de autonomia (e mesmo de influência) do corpo acadêmico no setor privado empresarial. A resistência a essa orientação é mais comumente encontrada no setor público, cujos atores, não sem razão, consideram esse processo como uma ameaça ao próprio ethos universitário. Com efeito, a subordinação do pessoal docente pelas mantenedoras (os proprietários das empresas de ensino) tem sido tão grande que, pelo menos no Brasil, conseguiu, até agora, impedir a emergência de uma organização sindical atuante, em contraste com o que se verifica no setor público.

Essas observações chamam a atenção para dois aspectos, já indicados por Levy (1986a), muito importantes dos sistemas de ensino superior contemporâneos: a heterogeneidade que carateriza o setor privado de ensino superior na América Latina e os vários arranjos que esse setor apresenta nos diferentes sistemas. Assim, enquanto em alguns países o setor privado distingue-se pela predominância de universidades confessionais, em outros, verifica-se uma combinação equilibrada entre instituições públicas, confessionais e de atendimento da demanda de massa; ainda em outros, em que o Brasil é um exemplo, constata-se a presença predominante de instituições do terceiro tipo.

Este trabalho constitui uma análise preliminar dessa diversidade e das dinâmicas próprias dos diferentes arranjos institucionais que essa diversidade conforma.

\section{OS DIFERENTES PERÍODOS DA EXPANSÃO DO SETOR PRIVADO}

crescimento do setor privado constitui um fenômeno geral na América, apesar de não ter ocorrido, nos países analisados, nem na mesma época nem com a mesma intensidade. Foi muito intenso no Brasil e na Colômbia nos anos 60 e 70. No Chile, Argentina e México, a expansão é mais recente, sendo característica do final dos anos 80 e 90. Essas diferentes ondas de expansão do setor privado são responsáveis pelo seu crescimento contínuo desde os anos 50 no conjunto da região.

Este trabalho considera o período posterior a 1950, pois foi a partir dessa data que a expansão dos sistemas nacionais de ensino superior começou a apresentar a sua complexidade atual. Para apreender essas diferentes dinâmicas de expansão, distinguimos, para fins da análise, três períodos. $\bigcirc$ período inicial corresponde à década que transcorre entre 1955 e 1965; o segundo período compreende de 1965 até o final da década de 70 e o terceiro, a década de 80 e o início dos anos 90. Em cada um dos períodos, duas variáveis são fundamentais: a expansão das matrículas no conjunto do sistema de ensino superior; a contribuição relativa dos setores público e privado nessa expansão.

\section{primeiro período: 1955-1965}

É no período entre 1955 e 1965 que, em quatro dos cinco países aqui considerados, se inicia a fase de grande expansão das matrículas de ensino superior, a qual se prolon- 
ga por toda a década seguinte. Apenas na Argentina a fase de grande expansão é anterior ao período focalizado neste trabalho. Todavia, qualquer que seja o período, o crescimento das matrículas de ensino superior nos países analisados assinala a passagem de sistemas de elite para sistemas mais abertos, capazes de incorporar maior contingente estudantil. Não é um fenômeno exclusivo da América Latina, mas faz parte, com algum atraso neste continente, de uma tendência mundial dos sistemas de ensino superior no Pós-Guerra (Clark, 1983).

Os dados da tabela I permitem colocar algumas questões relativas à interação entre sistemas nacionais de ensino superior, Estado e mercado, assim como à dinâmica entre setores público e privado em cada um dos países no período entre 1955- 1965.

TABELA ।

TOTAL DE MATRÍCULAS DE ENSINO SUPERIOR E PARTICIPAÇÃO RELATIVA DO SETOR PRIVADO - 1955-1975

\begin{tabular}{lcccccc}
\multirow{2}{*}{ País } & \multicolumn{2}{c}{1955} & \multicolumn{2}{c}{1965} & \multicolumn{2}{c}{1975} \\
\cline { 2 - 7 } & Total & Priv. \% & Total & Priv. \% & Total & Priv. \% \\
\hline Argentina & 151.127 & 1,0 & 246.680 & 8,0 & 596.736 & 12,0 \\
Brasil & 73.575 & 45,0 & $155.78 \mid$ & 44,0 & 1.072 .548 & 65,0 \\
Chile & $16.97 \mid$ & 36,0 & $41.80 \mid$ & 37,0 & 147.049 & 35,0 \\
Colômbia & 13.284 & 38,0 & 44.403 & 43,0 & 192.887 & 52,0 \\
México & 46.605 & $\mid 4,0$ & 133.374 & 15,0 & 506.287 & 15,0 \\
América Latina & 403.338 & 14,0 & 859.076 & 20,0 & $3.396 .34 \mid$ & 34,0 \\
A.Latina s/Brasil & 329.763 & 7,0 & 703.295 & 15,0 & 3.233 .793 & 19,0 \\
\hline
\end{tabular}

Fonte: Tabela elaborada a partir de dados de Levy (1992).

Conforme se verifica na tabela I, a Argentina é, conforme já notamos, um caso especial, pois o período em que se deu o crescimento das matrículas de ensino superior é anterior a 1955. Nesse país, a precocidade da expansão das matrículas em relação aos demais países considerados não implicou, todavia, a ampliação do sistema em termos de número de instituições de ensino superior. Tal expansão de matrículas coincide com o primeiro período peronista, de 1944 a 1955 e foi resultado, sobretudo, da adoção de uma política de ingresso irrestrito às universidades nacionais, públicas.

O crescimento das matrículas de ensino superior na Argentina se deu, portanto, até 1955, exclusivamente pela ampliação do número de vagas no setor público. Em 1955, a Argentina liderava com mais de um terço do total de matrículas de ensino superior na América Latina, com 150 mil estudantes matriculados. Em termos absolutos, isso significava mais que o dobro do total brasileiro. 
setor privado de ensino superior na Argentina era inexpressivo, absorvendo apenas 1\% das matrículas. Nos dez anos seguintes (1955-1965), as matrículas de ensino superior continuaram crescendo, porém num ritmo moderado. $\bigcirc$ Estado mantinha-se como o principal responsável por essa expansão; todavia, o setor privado começava, lentamente, a se desenvolver, mudando de patamar. Em uma década, a participação relativa das matrículas do setor privado passou de $1 \%$ para $8 \%$ do total de matrículas de ensino superior no país. Ainda que esse aumento não tenha introduzido nenhuma mudança na configuração do sistema argentino, ele representou um crescimento da ordem de $1.200 \%$ das matrículas em instituições particulares. Esse incremento deveu-se, em grande parte, ao processo que resultou na reforma universitária de 1958 e foi conseqüência dela. A precocidade da reforma universitária na Argentina, comparativamente às reformas que ocorreram no Chile e no Brasil, é outro fator que indica sua liderança nessa época. A reforma atuou, sobretudo, como elemento de modernização do sistema, buscando redefinir o modelo de universidade mediante a introdução da investigação científica e da diversificação da oferta curricular. Foi no ano da reforma que foi fundada a Universidade Católica da Argentina e data dessa época o reconhecimento e a autorização das universidades privadas para emitir títulos profissionais (Balán, 1993a). O reconhecimento das instituições privadas inscreveu-se no bojo de um amplo debate nacional polarizado nos termos "educação laica versus educação livre" (Della Paolera, 1993). A aliança entre a Igreja Católica e os setores liberais no movimento que destituiu Perón foi decisiva para a implantação da alternativa católica ao ensino superior estatal. Assim, o sistema de ensino superior argentino, que até então era quase que exclusivamente público e laico, centrado em poucas universidades, com um setor privado periférico (Geiger, 1986), dava os primeiros passos em direção à iniciativa não estatal no atendimento à demanda de ensino superior. Esse processo, apesar de pouco expressivo em termos percentuais, traduziu a passagem de um setor privado, que detinha pouco mais de 1.500 alunos, em 1955, para um de cerca de 20 mil alunos, em 1975, contribuindo para a ampliação do número e a diversificação das instituições de ensino superior.

Na história dos demais países, a expansão das matrículas de ensino superior foi posterior à da Argentina. Também, em todos eles, antes do início da expansão, a participação de um setor privado já era bem mais elevada. No Brasil, Chile e Colômbia, o setor privado respondia, em 1955, por mais de um terço das matrículas. O México vinha em seguida, numa posição intermediária entre esses países e a Argentina, com um setor privado responsável por 14\% das matrículas (o mesmo percentual da América Latina).

O Brasil, entre todos esses países, sempre se caracterizou pelo peso muito maior do ensino superior privado. Já em 1933, quando se deu início à coleta de informações estatísticas sobre educação no país, e, portanto, muito antes do período que estamos considerando, a participação relativa das matrículas do setor privado no sistema era de $45 \%$. A grande dimensão do setor privado no país ainda pode ser constatada nos dados 
gerais para a região: em 1955, quando o percentual das matrículas no setor privado era da ordem de $14 \%$ para o conjunto dos países do continente, se excetuarmos o Brasil, o percentual cai para $7 \%$.

No Brasil, o crescimento de mais de 100\% do total das matrículas de nível superior e a estabilidade da participação percentual das matrículas privadas entre 1955 e 1965 mostram dois processos concomitantes de crescimento: um do setor público, outro, do privado. $\bigcirc$ crescimento do setor público se deu, em grande parte, por iniciativa federal. $\bigcirc$ período compreendido entre o início dos anos 50 até o início da década de 60 corresponde ao processo de criação de universidades federais e/ou de federalização de universidades ou instituições isoladas privadas e estaduais (Mattos, 1983; Cunha, 1989). O segundo processo refere-se à manutenção da expansão do setor privado. Para apresentar, em 1965 , o mesmo patamar de participação percentual que apresentava em 1955, em um cenário de crescimento geral de matrículas, o setor privado também teve de ampliar muito a sua oferta de vagas. $\bigcirc$ crescimento das matrículas no setor privado, já nesse período, foi acompanhado de um processo incipiente de diferenciação das instituições de ensino superior. Nesse processo, destaca-se a existência, desde os anos 40, de uma rede de universidades católicas, que recebiam então substanciais recursos do Estado (Clark, 1983; Cunha, 1985). Essas instituições tendem a ser muito semelhantes às universidades públicas, constituindo um setor paralelo (Geiger, 1986) ao ensino superior público. Também, nesse período, constata-se o surgimento de instituições confessionais não universitárias e de estabelecimentos privados laicos que não são universidades. Esses estabelecimentos atendiam a uma dupla demanda: de um lado, por cursos de formação de profissionais liberais de alto prestígio, como faculdades isoladas de Medicina, Odontologia e Engenharia, mas também por cursos de baixo custo, como Direito; de outro, por cursos menos seletivos e de menor prestígio, como os de formação de professores para o $2^{\circ}$ grau, Ciências Contábeis, Pedagogia, entre outros².

Havia, contudo, uma demanda represada que pressionava pela ampliação de vagas no ensino superior. Essa foi a bandeira do movimento dos chamados "excedentes", isto é, candidatos aprovados nos exames vestibulares do setor público que não logravam classificação para ocupar as vagas, relativamente escassas, nos cursos oferecidos (Cunha, 1985, Martins, 1989). Essa bandeira foi incorporada pelo movimento estudantil, que pleiteava não só a expansão do número de vagas no setor público, mas também uma ampla reforma no sistema de ensino superior (Durham, 1993). Nesse contexto, o crescimento das matrículas de ensino superior, no Brasil, no período entre 1955 e 1965, embora constante, se deu de forma a preservar o equilíbrio entre o setor público e o privado.

2. No Brasil, o fato de a criação tardia de universidades ter-se dado por meio da aglutinação de escolas isoladas, aliado à manutenção de faculdades isoladas voltadas para a formação de profissões liberais, com o mesmo prestígio e tradição das universidades, concorreu para que não se estabelecesse, no país, um sistema de diferenciação de títulos ou diplomas outorgados por esses dois tipos de estabelecimentos (Durham, 1993). 
No México, de forma análoga à Argentina, e ao contrário do Brasil, o crescimento do sistema também foi sustentado pelo setor público e vinculou-se, em grande medida, à política de democratização do acesso às universidades públicas. No período de 1955 a 1965, as matrículas de ensino superior cresceram quase $200 \%$, enquanto a participação relativa das matrículas no setor privado subiu de 14\% para 15\% (ver Tabela I). A mesma observação apresentada para o Brasil e para a Argentina cabe ao México. Para manter esse percentual de participação em torno de 15\% em um quadro de crescimento geral de matrículas, o setor privado mexicano também experimentou um significativo crescimento, embora não tenha sido suficiente para alargar sua fatia de participação no total de matrículas de ensino superior nesse país.

No Chile, as matrículas do setor privado representavam, em 1955, 36\% do total das matrículas de ensino superior; dez anos depois, elas passaram a representar $37 \%$, o que mostra um quadro de estabilidade. Quando teve início a expansão das matrículas de ensino superior no Chile, o setor privado já respondia por mais de um terço delas. $\bigcirc$ mesmo fenômeno ocorreu no Brasil. Existe, contudo, uma diferença fundamental entre os setores privados no Brasil e no Chile. A marca dessa distinção residia, até 1980, no tipo de interação entre o Estado chileno e o sistema de ensino superior. No Chile, até bem recentemente, a demarcação entre setores público e privado era muito fluida e havia uma baixa diferenciação de status entre as instituições de ambos os setores (Clark, 1983; Levy, 1986a). As duas universidades estatais e as seis privadas tradicionais - três católicas e três laicas eram igualmente financiadas com recursos públicos (Cox, 1996). O repasse público consistia no financiamento incremental baseado em um orçamento prévio das alocações e também em uma fórmula de distribuição de recursos entre as universidades que variava em razão do montante de suas matrículas (Brunner, 1986).

Os dados da tabela I, para o caso chileno, portanto, devem ser lidos com uma certa cautela. A distinção, baseada na origem do financiamento, entre ensino público e ensino privado não se aplica, integralmente, no sistema de ensino superior chileno. Embora no período entre 1955 e 1965 o setor privado no Chile tivesse mantido uma taxa de participação no total de matrículas de ensino superior em torno de 35\%, é preciso notar que essa estabilidade na participação se deveu, em muito, ao financiamento estatal às universidades privadas e não ao próprio financiamento privado, proveniente de anuidades estudantis, como se verificou nos demais países.

Na Colômbia, como no Brasil e no Chile, as matrículas privadas sempre tiveram um peso considerável. Já em 1955, o setor privado respondia por 38\% das matrículas de ensino superior. Com um sistema de dimensão reduzida, com pouco mais de 13 mil alunos, essa taxa de participação do setor privado equivalia a aproximadamente cinco mil alunos que, com grande probabilidade, poderiam estar distribuídos em algumas poucas instituições privadas, boa parte delas, católicas. Nesse país, as universidades católicas, embora não recebessem financiamento estatal integral, como ocorria no Chile, sempre tive- 
ram acesso a significativos recursos públicos, quer mediante o financiamento direto, quer por meio de outros mecanismos de repasse, como o crédito educativo (Levy, 1986).

Na realidade, a configuração de um setor privado católico, que funcionou de forma paralela ao setor público até a década de 70, teve sua origem na alternância entre dois modelos de universidade, a estatal laica e a privada confessional, sustentada, pelo menos parcialmente, pelo Estado. Os dois modelos foram concorrentes e se alternaram, na Colômbia, durante todo o século XIX e parte do século XX (Lúcio, Serrano, 199I; Klein, Sampaio, 1996). A alternância correspondia à hegemonia política que, em cada período, consolidou determinada facção ou aliança de facções. Desse modo, quando o Estado estava em mãos anticlericais, as ordens religiosas eram expulsas e se restabelecia o controle das universidades laicas. Por sua vez, a hegemonia dos grupos conservadores implicava o retorno dos católicos e seu controle sobre o sistema educacional e o enfraquecimento da universidade laica. Essa situação se manteve durante todo o século XIX, e adentrou nas primeiras décadas deste século, quando se iniciou, em 1930, o processo de modernização e secularização do Estado colombiano. Além de tardia, a secularização do Estado colombiano foi menos radical que em outros países latino-americanos, entre os quais o México é o melhor exemplo (Klein, Sampaio, 1996; Lúcio, Serrano, 1991). Assim, no período entre 1955 e 1965, o que ocorreu na Colômbia foi a manutenção desses dois setores paralelos, constituídos, respectivamente, por instituições públicas e laicas e privadas confessionais ou semi-estatais.

No decorrer desse período, com exceção da Argentina e com algumas variações conjunturais, o que se observa é uma expansão concomitante dos setores público e privado, com a tendência à manutenção do equilíbrio relativo entre ambos.

\section{segundo período: 1965-1975}

Nos dez anos seguintes, de 1965 a 1975, presenciam-se transformações bem mais profundas nos sistemas de ensino superior dos países considerados. Em primeiro lugar, a expansão do ensino superior se acelerou muito. No conjunto da América Latina, as matrículas de ensino superior passaram de 859 mil, em 1965, para quase 3,4 milhões, dez anos depois. Isto é, multiplicou-se por quatro, enquanto na década anterior havia apenas duplicado.

O crescimento maior ocorreu no Brasil (668\%), seguido da Colômbia (334\%), México (275\%), Chile (25।\%) e Argentina ( $142 \%)$. Uma explicação para esse crescimento menor na Argentina é o fato de esse país ter passado por três décadas de crescimento ininterrupto de matrículas de ensino superior (ver Tabelas I e 2). Os demais países parecem atender a uma demanda represada ${ }^{3}$ que a Argentina já teria atendido.

Quanto ao crescimento relativo das matrículas do setor privado, o comportamento

3. Para se ter uma idéia desse represamento, em 1955, as matrículas de ensino superior no Brasil representavam a metade do total das matrículas de ensino superior na Argentina; 20 anos depois, foi o Brasil que passou a ter o dobro das matrículas de ensino superior da Argentina. 
dos diferentes países é variado. No Chile e no México, onde o crescimento total das matrículas esteve perto de 250\%, o setor privado manteve-se estável (no Chile declina um pouco, inclusive). Na Argentina, a participação relativa das matrículas do setor privado foi reduzida, passando de $8 \%$ para 12\%. No Brasil e na Colômbia, essa participação atingiu, respectivamente, $65 \%$ e $52 \%$ do total de matrículas de ensino superior.

No caso da Argentina, o constante aumento, ainda que reduzido, da participação relativa das matrículas no setor privado, não deixa de ser significativo e está associado ao cenário político do país. A partir de 1966, a instabilidade institucional e a repressão política contribuíram não só para interromper o crescimento e a desconcentração regional do setor público de ensino superior no país, mas também para desorganizar as atividades acadêmicas, especialmente na Universidade de Buenos Aires. Foi no período entre 1976 e 1977, o mais repressivo do regime militar, que as matrículas no setor público de ensino superior efetivamente diminuíram. Nesse quadro, o setor privado, notadamente a Universidade Católica Argentina, constituiu-se em uma alternativa ao ensino superior público, oferecendo maiores possibilidades de formação acadêmica regular. Havendo também o governo militar deixado de investir na pesquisa universitária e na formação do quadro docente, a qualidade do ensino superior público decaiu (Balán, 1993). Acresce-se, ainda, nesse quadro de deterioração do ensino superior público, o êxodo de intelectuais promissores, sem condições políticas e financeiras para desenvolverem suas atividades de pesquisa, bem como o gigantismo das universidades, provocado pelo ingresso irrestrito.

No México, a expansão do ensino superior também esteve associada a uma política de liberalização do ingresso à universidade pública. Ainda que o ingresso não tivesse caráter totalmente irrestrito, como acontecia na Argentina, ele era, no mínimo, pouco seletivo. Os estudantes que freqüentavam os cursos pré-universitários oferecidos pelas universidades públicas tinham acesso imediato a essas instituições. Como não havia controle para matricular-se nesses cursos pré-universitários, o ingresso na universidade pública era, praticamente, automático ${ }^{4}$. Nesse contexto, o setor privado manteve-se, praticamente, estável no período 1965-1975 (ver Tabela I). Deve ser notado, entretanto, que essa estabilidade da participação relativa das matrículas no setor privado exigiu um crescimento substancial em números absolutos. $\bigcirc$ crescimento das matrículas públicas, nesse país, decorrente da política de liberalização do acesso à universidade pública, provocou, à semelhança do que ocorreu na Argentina, um agigantamento dessas instituições, sendo a Universidade Metropolitana do México o melhor exemplo. Mesmo recebendo fluxos de recursos estáveis do Estado, ao longo de toda a década de 70, as universidades públicas mexicanas não conseguiram preservar seu padrão de excelência (Klein, Sampaio, 1996). A dimensão que estavam assumindo dificultava a preservação de sua qualidade acadêmica ${ }^{5}$.

4. Rollin Kent, comunicação pessoal.

5. Na Argentina, esse problema foi ainda mais grave devido aos cortes orçamentários para as universidades públicas, realizados durante os governos militares, como forma de puni-las, inclusive. 
Nesse contexto, uma parte do setor privado, representado por algumas instituições laicas e outras confessionais, que restringiram o acesso, mediante exames de seleção e cobrança de anuidades dos alunos, consolidou seu prestígio acadêmico e apresentou-se como alternativa valorizada em relação ao ensino superior público. $\bigcirc$ Instituto Tecnológico de Monterrey é o exemplo clássico dessa alternativa privada de elite ao ensino público de massa. Para Levy (1986a), a criação dessas instituições laicas de elite representa uma segunda fase do processo de privatização do ensino superior na América Latina - embora essa onda seja, muitas vezes, contemporânea ao aparecimento, em outros países, de instituições privadas de atendimento à demanda de massa. Segundo esse autor, o movimento de criação dessas instituições privadas expressa o descontentamento de setores das elites com o ensino oferecido pelo setor público e sua resistência ao ensino confessional. Balán (1993) acrescenta ao descontentamento pela qualidade, outro, de natureza política. Para esse autor, a existência de grupos liberais que se opunham ao esquerdismo imperante no ambiente das universidades públicas foi um elemento importante para o desenvolvimento dessa alternativa privada - laica ou confessional - ao ensino público.

No México, ainda, ao lado das instituições laicas de elite e de algumas universidades católicas, foram criados, no auge da expansão do sistema, e à semelhança do que havia ocorrido no Brasil, estabelecimentos particulares não universitários com uma oferta reduzida de cursos, em geral concentrados nas áreas de Humanidades e de Ciências Sociais Aplicadas. $O$ setor privado mexicano, que surgiu nesse período de expansão, apesar de muito heterogêneo, teve um peso pequeno no sistema de ensino superior mexicano, que se manteve então predominantemente público.

Constata-se, assim, tanto no México como na Argentina, que, apesar de conjunturas político institucionais distintas, a absorção da demanda de massa de ensino superior pelo setor público, mediante políticas de ingresso irrestrito, ou quase, inibiu, no período, o desenvolvimento de um mass private sector, segundo a terminologia de Geiger ( 1986), ou de um setor privado de satisfação de demanda, segundo Levy (1986a). Nesses países, a iniciativa privada orientou-se antes para atender à demanda de elites locais descontentes com a deterioração do ensino público (Levy, 1986) e, segundo Balán (1993), com a excessiva politização do ambiente universitário público. Nesses países, a interação entre setor público e privado de ensino superior adquiriu, portanto, novos contornos.

A grande expansão do sistema de ensino superior chileno ocorreu entre 1968 e 1973, anterior portanto à instalação do regime militar autoritário. Essa expansão foi conduzida pelo setor estatal, por meio da criação de novas universidades e da ampliação das já existentes, mediante instalação de sedes regionais. No período 1965-1975, as matrículas totais mais do que triplicaram, passando de cerca de 42 mil estudantes para cerca de 147 mil. Ademais, o período também foi rico em inovações para o sistema. A Universidade do Chile, por exemplo, atuou como uma ponta de lança no processo de modernização do ensino superior do país. Com base em iniciativas que partiram de sua própria liderança 
acadêmica e que passaram ao largo da área governamental, ela introduziu mudanças na moldura institucional da pesquisa e criou mecanismos de articulação entre a universidade e a sociedade em geral, e o setor produtivo em particular. Um dos objetivos das mudanças era o de romper com o modelo tradicional de pesquisa concentrado nas Ciências Naturais e adquirir competência nas novas áreas tecnológicas, nas áreas agrárias e nas Ciências Sociais. A ampliação e a redefinição da estrutura de pesquisa foram viabilizadas por um fluxo constante de recursos externos (Fuenzalida, s.d.; Klein, Sampaio, 1996).

No Chile, como no Brasil, o acesso ao ensino superior público sempre foi mais restrito, dependendo de aprovação em exame específico. Isso sem dúvida foi um fator decisivo para a manutenção, em ambos os países ${ }^{6}$, de um setor público de tamanho mais reduzido, comparativamente aos sistemas mexicano e argentino, e que preservou prestígio acadêmico. Além do mais, o Estado chileno, comparativamente aos Estados brasileiro e colombiano - cujos países também já contavam com setores privados de grande dimensão -, parece ter exercido maior controle sobre o crescimento do sistema e, em especial, sobre a expansão do setor privado.

Na Colômbia, entre 1965 e 1975, as matrículas totais no ensino superior cresceram 334,4\%, caracterizando o período de maior expansão do ensino superior no seu conjunto. $O$ setor privado que respondia por $43 \%$ passou a absorver mais da metade do total de matrículas de ensino superior. Em números absolutos, isso representou mais de 100 mil estudantes matriculados no setor privado. A absorção desse montante de alunos não poderia ter se dado somente pelo incremento de vagas nas universidades tradicionais católicas ou nos institutos laicos de elite. Essa absorção foi feita por um novo setor privado de atendimento à demanda de massa, como havia se dado no Brasil. Nesse país, assim como no México, não houve reforma universitária no período que antecedeu à expansão do sistema de ensino superior. Um dos efeitos da ausência de uma reforma foi o enfraquecimento da universidade pública. De um lado, porque sendo incapaz de suprir a demanda por formação superior, o setor público abriu para a iniciativa privada espaço para a criação de estabelecimentos menos seletivos, voltados ao atendimento de uma clientela crescente que buscava formação superior. $\bigcirc$ incremento dessa clientela fazia parte do processo de urbanização relativamente recente do país (Lúcio, Serrano, I99।). De outro lado, o setor público, especialmente o segmento universitário, perdeu prestígio; sem reforma, ressentiu-se, aos olhos das elites locais, de uma lufada modernizante. Nesse cenário, alguns institutos privados laicos mais seletivos começam a ter um peso diferencial no sistema, atraindo jovens das camadas sociais de maior poder aquisitivo.

Na Colômbia, contanto, tal como ocorreu no Brasil, o setor privado foi o carro-

6. Excetuando a ampliação da rede de universidades federais no Brasil e a criação de sedes regionais das grandes universidades tradicionais no Chile, a opção foi a de limitar o crescimento do setor público, tanto no que diz respeito à oferta de vagas e à contratação de professores como quanto à criação de novas instituições (Klein, Sampaio, 1996). 
chefe da expansão do sistema de ensino superior. Diferentemente do Brasil, entretanto, o setor público colombiano saiu duplamente perdedor: não só diminuiu sua participação relativa no sistema, mas também perdeu prestígio. $\bigcirc$ setor privado, por sua vez, tendeu a se expandir nas extremidades do sistema: o de maior prestígio e o de menor qualidade.

O Brasil é o país que apresenta, nesse período, o maior crescimento global das matrículas de ensino superior. É também o país onde o setor privado mais cresceu. Até 1968, assistiu-se a intensa resistência política promovida pelo movimento estudantil, com amplo apoio docente, ao regime militar que se instalara em 1964. Nesse cenário conturbado politicamente, ergueu-se novamente a bandeira da reforma universitária e da ampliação do número de vagas no ensino público. $\bigcirc$ ideal era o estabelecimento de um modelo uniforme, constituído exclusivamente para universidades públicas e gratuitas, e que associasse o ensino à pesquisa (Durham, 1993). Em 1968, foi decretada a reforma universitária; também nesse ano foi editado o Ato Institucional n.5, inaugurando a fase mais repressiva do regime militar.

A reforma de 1968 incidiu especialmente sobre as universidades. Por isso atingiu, basicamente, o setor público e as poucas universidades privadas confessionais. $\bigcirc$ setor privado de ensino era formado, em sua maioria, por instituições não universitárias e, sendo assim, foi muito menos atingido.

A ação da reforma sobre o setor público foi essencialmente qualitativa: além de criar um espaço para a pesquisa dentro da universidade e de estimular a profissionalização dos docentes, por meio da incorporação ao regime de tempo integral, vinculou a ascensão na carreira ao aumento da qualificação e ao treinamento em pesquisa. Criou-se, com isso, uma clientela crescente para os programas de pós-graduação que, nessa época, começavam a se instalar no país e que vieram a ter, na década de 70, notável expansão. Como conseqüência, elevou-se substancialmente o custo aluno no setor público. Por isso mesmo, as matrículas de graduação no setor público, embora também tivessem crescido, sobretudo mediante a ampliação do número de vagas em universidades federais, não foram suficientes para fazer frente à demanda crescente de formação superior oriunda dos setores médios urbanos que, nessa época, também estavam se ampliando (Durham, 1993; Schwartzman, 1992). De certo modo, a política de ingresso às universidades públicas, continuando a ser seletiva, manteve o setor público com dimensões mais restritas.

Nessas circunstâncias, o setor privado de ensino superior teve possibilidade de atender à demanda reprimida do grande número de candidatos que não conseguia ingressar nas universidades públicas. $\bigcirc$ setor privado ampliou-se por meio de instituições não universitárias, de pequeno porte, que passaram a oferecer cursos de baixo custo em carreiras como Letras, Ciências Humanas e, principalmente, Ciências Sociais Aplicadas (Direito, Economia, Administração, Contabilidade). A participação relativa dos estabelecimentos privados no sistema sempre foi maior que a participação relativa de suas matrículas, o que evidencia o processo de pulverização da oferta privada de ensino superior. No Brasil, coube ao setor 
privado atender à massificação do ensino superior desencadeada já no final dos anos 60 , dele se beneficiando. Os benefícios correspondiam a retornos financeiros muito significativos, derivados de uma inserção fácil em um mercado pouco seletivo e altamente lucrativo, em razão da existência da demanda reprimida. Os custos dessa massificação, contudo, recaíram sobre todo o sistema: a proliferação de instituições de baixa qualidade (Martins, 1989). As normas para regulamentar a expansão do ensino superior, nesse período, em que pesem algumas recomendações pontuais do Ministério da Educação visando controlar seu crescimento desordenado, foram meramente burocráticas e ineficazes. Era o mercado e não o Estado que passava a moldar o crescimento do setor privado no Brasil. Com efeito, ao longo desses 20 anos, de 1955 a 1975, o setor privado deixou de ser um setor paralelo, com status e funções relativamente similares às do setor público, para se constituir em um mass private sector (Geiger, 1986), complementando o setor público mais seletivo e de maior prestígio.

\section{O ESTADO, O SETOR PÚBLICO E O PRIVADO NAS DÉCADAS DE 80 E 90}

Os anos 80 inauguram uma nova fase para os sistemas de ensino superior dos países latino-americanos. As razões desse marco podem ser alinhadas em torno de dois eixos: o primeiro refere-se à consolidação da participação ampliada do ensino superior privado. O segundo, à redefinição, nos diferentes países, da relação do Estado com os respectivos sistemas nacionais de ensino superior.

Em que pesem as oscilações entre diferentes fontes estatísticas para o período, é possível notar algumas tendências gerais. A primeira é a queda no ritmo de crescimento das matrículas totais de ensino superior em quase todos os países, com exceção da Argentina. A segunda tendência é o aumento da participação relativa das matrículas do setor privado em quase todos os sistemas nacionais de ensino superior, com exceção do Brasil.

De acordo com a tabela 3, na Argentina, o crescimento de 95,7\%, no período 1982-1991, mostra antes uma recuperação do sistema diante do refluxo verificado no período anterior à década de 80 . $\bigcirc$ decréscimo das matrículas de ensino superior, que ocorreu entre 1975 e 1982, bem como a recuperação posterior, devem ser interpretados à luz dos acontecimentos políticos do país. Alterações na ordem político-institucional refletiram-se diretamente no financiamento do ensino superior público e são responsáveis, em grande medida, pela oscilação que se verifica nas matrículas. Nos anos de 1976 e 1977, os recursos para as universidades nacionais apresentaram uma taxa de variação anual negativa de 46,9\% em relação aos anos anteriores, resultando em uma diminuição acentuada nas matrículas (Balán, 1993a) ${ }^{7}$. Superada essa fase, registrou-se uma recuperação no financia-

7. Nesse período, os cortes no financiamento das grandes universidades faziam parte de uma estratégia de redistribuição de recursos baseada em critérios políticos. Assim, enquanto declinavam os recursos para as grandes universidades nacionais, parte substantiva deles foi direcionada a instituições menores e mais complacentes com o regime. Nesse 
TABELA 2

PERCENTUAL DAS MATRÍCULAS NO SETOR PRIVADO SOBRE O TOTAL DE MATRÍCULAS DE ENSINO SUPERIOR - 1980-1994

\begin{tabular}{lccc} 
País & Ano & Matrícula total & $\begin{array}{c}\text { Percentual de } \\
\text { matrículas privadas }\end{array}$ \\
\hline Argentina & 1982 & 550.556 & 22,0 \\
& 1991 & 1.077 .212 & 15,0 \\
Brasil & 1994 & 1.054 .145 & 20,0 \\
& 1980 & 1.389 .518 & 63,3 \\
Chile & 1990 & 1.558 .468 & 62,5 \\
& 1994 & 1.661 .034 & 58,4 \\
& 1980 & 118.978 & 37,0 \\
Colômbia & 1990 & 249.482 & 52,0 \\
& 1994 & 327.084 & 53,6 \\
& 1981 & 306.269 & 59,0 \\
México & 1989 & 474.787 & 57,0 \\
& 1994 & 561.223 & 64,1 \\
& 1981 & 785.419 & 15,0 \\
& 1990 & 1.078 .190 & 17,0 \\
\hline
\end{tabular}

Fonte: Quadro elaborado com base em dados de Brunner (1993) e Garcia (1997).

mento público para as universidades nacionais (públicas). Todavia, os montantes destinados a essas instituições em 1980, ano de maior afluência de recursos para o ensino superior durante todo o regime militar, ainda eram inferiores aos índices alcançados no ano de 1974 (Balán, 1993a). Essa é uma das causas que explicaria a diminuição das matrículas de ensino superior na Argentina a partir da segunda metade da década de 70 bem como a sua recuperação que se inicia nos anos 80 , com o governo Alfonsin.

No decorrer da década de 80, na Argentina, sob governos civis, é possível identificar dois momentos distintos na política de financiamento das universidades nacionais. $\bigcirc$ primeiro, compreendido entre 1983 e 1988, caracterizou-se por uma expansão do gasto em educação e pelo aumento das matrículas, com o retorno da política de ingresso irrestrito às universidades públicas. O segundo período, de 1988 a 1990, foi marcado por uma

processo de realocação de recursos, em que o volume do financiamento era inversamente proporcional às necessidades reais, o maior beneficiário foi o setor terceiro não universitário que se expandiu em um ritmo acelerado nesse período (Klein, Sampaio, 1996). Na Argentina, o setor terceiro é formado por instituições isoladas que têm por objetivo formar professores para a educação média (Marquis, 1992). 
TABELA 3

PERCENTUAL DE CRESCIMENTO DO TOTAL DE MATRÍCULAS DE ENSINO SUPERIOR E DAS MATRÍCULAS DO SETOR PRIVADO - 1980-1994

\begin{tabular}{lccc} 
País & Ano & $\begin{array}{c}\text { Crescimento da } \\
\text { matrícula total (\%) }\end{array}$ & $\begin{array}{c}\text { Crescimento da } \\
\text { matrícula privada (\%) }\end{array}$ \\
\hline Argentina & $1982 / 1991$ & 95,7 & 33,4 \\
Brasil & $1991 / 1994$ & $-2,1$ & 30,5 \\
& $1980 / 1990$ & 10,8 & 1,4 \\
Chile & $1990 / 1994$ & 7,9 & 0,9 \\
& $1980 / 1990$ & 9,7 & 194,7 \\
Colômbia & $1990 / 1994$ & 31,1 & 35,1 \\
& $1981 / 1989$ & $-55,0$ & 49,8 \\
México & $1989 / 1994$ & $-18,5$ & 32,9 \\
& $1981 / 1990$ & $-37,3$ & 55,6 \\
\hline
\end{tabular}

Fonte: Quadro elaborado com base em dados de Brunner (1993) e Garcia (1997).

redução gradativa, porém constante, dos gastos públicos para o ensino superior, como parte de um conjunto de reformas visando ao ajuste fiscal. Com efeito, entre 1991 e 1994, as matrículas de ensino superior nesse país registraram taxa de crescimento negativo da ordem de $2 \%$, conforme se vê na tabela 3.

Nesse contexto, chama a atenção o comportamento do setor privado de ensino superior na Argentina. Os anos em que o sistema se contraiu, em conseqüência de cortes orçamentários para as grandes universidades nacionais, correspondem ao período de maior participação relativa das matrículas do setor privado. Em 1982, o setor privado respondeu por $22 \%$ das matrículas de ensino superior que, por sua vez, tinham decrescido em relação ao ano de 1975. A recuperação do setor público entre 1982 e 1991, reflexo do incremento dos gastos para o ensino superior, provocou, por seu turno, diminuição da participação relativa das matrículas do setor privado. Inversamente, em 1994, quando houve taxa negativa de crescimento das matrículas totais, o setor privado aumentou para 20\% sua participação relativa no sistema. Embora tenha ocorrido aumento, o setor privado não conseguiu atingir o índice de 1982, quando o sistema estava, efetivamente, mais comprimido (Tabela 2).

O setor privado na Argentina parece cumprir uma função suplementar ao setor público: aumenta e diminui a participação relativa de suas matrículas no sistema de ensino superior em conformidade com o fluxo de recursos do Estado para as universidades nacio- 
nais. Paolera (1993), entretanto, apresenta uma interpretação diferente. Para esse autor, o rápido e recente crescimento da participação relativa das matrículas do setor privado no sistema argentino é uma das conseqüências da crise econômica pela qual passou o país entre 1989 e 1990 e corresponderia a uma segunda etapa da privatização do ensino superior nesse país. Segundo Paolera, a crise de 1989/1990, resultante de mudanças estruturais visando dinamizar e tornar mais competitiva a economia no país, deflagrou um aumento no preço relativo dos custos de ensino superior privado. $\bigcirc$ aumento, por sua vez, provocou uma situação de demanda insatisfeita pela qualidade da formação superior oferecida pela iniciativa privada. Entre 1989 e 1992, segundo dados fornecidos por Paolera (1993), a Universidade Católica Argentina aumentou a taxa de matrícula cobrada de seus alunos em cerca de $82 \%$ em termos absolutos. Também a Universidade de Belgrano (particular) aumentou em $213 \%$ em termos absolutos nesse mesmo período. A alteração no preço relativo do ensino superior, em um contexto de oferta limitada e demanda crescente, seria um dos fatores que levaram, segundo a análise de Paolera, muitas instituiç̧ões que já tinham vantagens competitivas na área de docência e/ou na de pesquisa em outros níveis educacionais, a se estabelecerem como universidades. Entre os novos estabelecimentos criados recentemente constam a Associação Civil Escocesa San Andrés, com mais de um século de prestígio em ensino de nível fundamental e médio, a qual criou, em 1989, a Universidade de San Andrés. Também a Fundação e o Instituto Torquato Di Tella, pioneiros no desenvolvimento de pesquisas na área de Ciências Sociais, fundam uma universidade com o mesmo nome. Somam, nesse conjunto de universidades privadas recém-criadas, a Universidade Maimonides, a Universidade Austral, a Universidade de Palermo e a Universidade Adventista, entre outras. Entre 1987 e 1995, duplicou o número de universidades privadas no país, passando de 23 para 46 (Fanelli, 1997).

surgimento dessas novas instituições na Argentina consolidou e diversificou o setor privado de ensino superior. $\bigcirc$ mercado, até então quase monopolizado pelo Estado, tornou-se dual: de um lado, encontra-se uma oferta de ensino superior gratuito, autônomo e mantido pelo Estado; de outro, um serviço pago, oferecido pela iniciativa privada, extremamente competitivo no recrutamento de alunos e também muito heterogêneo no que diz respeito à qualidade do serviço que oferece.

No Brasil, embora não tenha havido um decréscimo das matrículas de ensino superior nesse período, houve, certamente, uma estagnação. A taxa de crescimento diminuiu de forma considerável em relação à década de 70. Em dez anos (1980-1990), as matrículas totais cresceram apenas 10,8\%; entre 1990 e 1994, o crescimento foi de 7,9\%.

Diferentemente da Argentina, onde a diminuição do índice de crescimento das matrículas de ensino superior resultou, sobretudo, da redução dos recursos do Estado para as universidades nacionais, no Brasil a desaceleração do crescimento das matrículas de ensino superior faz parte de outra dinâmica.

Em primeiro lugar, no Brasil, não se verificou, no decorrer dos anos 80 , redução 
substancial do financiamento público para o ensino superior. Em segundo lugar - e essa é uma diferença fundamental entre os dois países - a expansão do sistema de ensino superior no Brasil, que ocorrera na década anterior, foi liderada pelo setor privado. Sendo assim, foi a resposta da iniciativa privada à demanda de mercado que orientou o ritmo de crescimento do ensino superior e, em grande parte, foi a poupança privada que financiou a grande expansão do sistema da década de 70. Em meados da década de 1980 esse mercado já estava plenamente atendido, o que explica o ligeiro declínio da sua participação nas matrículas no período. Nesse quadro, o que chama a atenção é o aumento dos gastos com pessoal do setor público que quase quintuplicaram ${ }^{8}$ entre 1974 e 1989. A exceção foi o período de 1980/1984, quando os gastos com pessoal foram reduzidos e, mais recentemente, o período que se iniciou em 1990 e vem se prolongando até o presente, em que as despesas com pessoal têm declinado de forma acentuada (Schwartzman, 1993). Nesse sentido, a despeito da crise financeira enfrentada pelo Estado brasileiro desde 1977, o orçamento das universidades federais escapou, durante boa parte, nos últimos 20 anos, do rigor dos cortes orçamentários executados pelas autoridades da área econômica. Isso se deveu a dois fatores: de um lado, à vinculação constitucional de percentual da receita de impostos para a educação ( $18 \%$ no caso da União e $25 \%$ no caso de estados e municípios); de outro, há que se considerar os benefícios concedidos aos funcionários públicos (entre os quais se inclui o pessoal das universidades públicas), como a estabilidade no cargo e a irredutibilidade de vencimentos. Nesse quadro, o orçamento das universidades federais tornou-se inelástico, sem que a manutenção de recursos estivesse associada ao aumento do número das matrículas.

O crescimento tímido das matrículas de ensino superior no Brasil - menos de 8\% que se verificou entre 1990 e 1994 - resultou, além dos fatores acima apontados, de um outro muito relevante: o estrangulamento que atingiu nos níveis anteriores de ensino (fundamental e médio). As matrículas no ensino superior deixaram de apresentar o mesmo ritmo de crescimento, verificado nas décadas anteriores, porque havia um represamento nos níveis anteriores ao ensino superior: poucos lograram ingressar e, menos ainda, concluir o ensino de nível médio. Em algumas regiões, notadamente na Região Sudeste, havia mais vagas no ensino superior do que egressos do ensino médio. Nesse contexto, constata-se também a redução da participação relativa das matrículas do setor privado (Tabela 2). ○ crescimento do setor privado, no período anterior, deu-se pela absorção de uma de-

8. A propósito, deve ser notado que mais do que o crescimento do número de instituições federais, do aumento de seu quadro de professores, ou da melhoria de sua titulação, a grande expansão dos gastos com pessoal, a partir de 74, decorreu, sobretudo, do impacto da introdução do regime de tempo integral sobre a folha de pagamento das universidades federais. De acordo com Schwartzman (1993), a estratégia das universidades federais foi a de ampliar ao máximo a proporção de professores de tempo integral já que os custos da implantação do novo regime recaíam sobre o Ministério da Educação, que é quem paga os salários. Esse fato, acrescido da ausência de critérios para a adoção da nova política, explica por que algumas universidades funcionam, atualmente, com quase $100 \%$ dos professores em regime de dedicação exclusiva. 
manda represada constituída - além dos egressos do ensino médio, cuja rede também tinha se ampliado naquele período -, por um contingente de pessoas mais velhas, já inseridas no mercado de trabalho, e também pelo aumento do contingente feminino a aspirar a uma formação de nível superior (Schwartzman, 1992). Além desse fenômeno da diminuição da demanda, o declínio percentual das matrículas privadas, entre 1990 e 1994, também está associado ao aumento das matrículas do segmento público estadual. Em 14 anos - de 1980 a 1994 - as matrículas nas universidades estaduais, gratuitas, tiveram um crescimento ${ }^{9}$ de mais de 130\%. Essa taxa foi superior até à verificada nas matrículas das universidades privadas, de $86,6 \%$, para esse mesmo período. Com efeito, o crescimento das matrículas no segmento das universidades estaduais contribuiu para manter significativa a participação relativa das matrículas do setor público no sistema de ensino superior.

Também, no México, constata-se, desde 1980, uma apreciável diminuição na taxa de crescimento das matrículas no ensino superior comparativamente à década de 70 . Entre 1981 e 1990, a taxa de crescimento foi de 55\%, decrescendo para 20\% entre 1990 e 1994. Mesmo com essa redução, o México apresentou, de todos os países analisados, a maior taxa de crescimento de matrículas de ensino superior no período.

Deve-se notar que, no México, até o final da década de 70, quando grande parte dos Estados latino-americanos já enfrentava escassez de recursos, as dotações orçamentárias para universidades públicas tiveram até um reforço. Mas a partir de 1982, a crise fiscal do Estado, aliada à redução dos preços internacionais do petróleo, levaram a uma diminuição do orçamento das instituições de ensino superior estatais, com um forte impacto sobre o gasto público em ensino superior. Entre 1981 e 1989, os gastos governamentais com o sistema diminuíram em cerca de 25\%, passando de I\% do PIB, em 198I, para 0,7\%, em 1989 (Kent, 1995).

De forma semelhante ao que vem ocorrendo na Argentina, no México a participação relativa das matrículas privadas vem aumentando desde 1990 (Tabela 2). Esse crescimento contínuo é muito significativo nesse país, onde, durante quase meio século, a participação percentual do setor privado nas matrículas de ensino superior esbarrava no teto de I5\% e onde o setor público foi o grande responsável pela expansão do sistema.

A dimensão relativamente reduzida do setor privado no México e na Argentina, no período anterior, vincula-se, certamente, ao fato de que, em ambos os países, desenvolveu-se um mass public sectorao invés de um mass private sector (Geiger, 1986). O crescimento recente das matrículas privadas parece indicar a exaustão da capacidade dos respectivos Estados de continuar a arcar com os custos da ampliação do setor público de forma a atender à demanda de ensino superior em grande escala.

Com efeito, em apenas três anos, de 1990 a 1993, no México, o número de

9. As matrículas nas universidades estaduais nesse período passaram de 81.723 para 190.27। (Pesquisa em andamento no Núcleo de Pesquisas sobre Ensino Superior da Universidade de São Paulo). 
estabelecimentos isolados particulares de ensino superior passou de 162 para 203. Em 1993, esses estabelecimentos representavam 47,2\% do total de instituições de ensino superior no país. Trata-se, em sua maioria, de instituições de pequeno porte, que oferecem cursos nas carreiras de Contabilidade, Administração, Hotelaria e Turismo (Kent, 1995). Também, nesse período, foram criadas mais cinco universidades particulares. Em 1993, essas instituições eram 55, superando, em número, as universidades públicas, que somavam 46. No período entre 1990 e 1993, o crescimento das matrículas nos estabelecimentos particulares isolados foi de 34\%, passando de 65.819 para 88.296; no segmento das universidades privadas, o crescimento percentual das matrículas foi de $23 \%$, passando de I 21.305 para 148.964 (Kent, 1995). A ampliação recente se dá, portanto, à semelhança do caso da Colômbia, nas duas pontas do sistema: na de alto e na de baixo prestígio.

Apesar desse movimento que se verifica nos últimos anos no México - de ampliação do número de estabelecimentos privados e de suas matrículas e, inversamente, de diminuição das matrículas nas universidades nacionais públicas -, o setor público mexicano ainda respondia, em 1994, por 74,8\% das matrículas totais de ensino superior (ver Tabela 2).

Em suma, tanto no México como na Argentina, o aumento da participação relativa das matrículas do setor privado nos respectivos sistemas nacionais de ensino superior só logrou ultrapassar o patamar de $20 \%$ quando diminuiu o ritmo da expansão das matrículas totais $^{10}$. A correlação sugere que a possibilidade de expansão do setor privado nos países em que o setor público voltou-se para o atendimento em grande escala depende mais da incapacidade dos respectivos Estados de manter o ritmo de crescimento do sistema do que, como ocorre atualmente no Brasil, da ampliação da demanda de ensino superior.

Na Colômbia verifica-se também que o ímpeto de crescimento das matrículas de ensino superior não é o mesmo da década de 70, embora elas continuem crescendo. Entre 1981 e 1989, a taxa de crescimento das matrículas totais foi de 55\%; entre 1989 e 1994, de 18,2\%. Apesar desse decréscimo, na Colômbia, a taxa de crescimento das matrículas de ensino superior mantém-se superior às taxas dos demais países. Entretanto, também como ocorre nos outros países latino-americanos considerados, a Colômbia, desde os anos 80, vem enfrentando dificuldades no financiamento das universidades públicas. Durante longos períodos do ano de 1980, boa parte das universidades estatais esteve fechada por falta de recursos (Lúcio, Serrano, 1993). As medidas do governo no sentido de instituir novas políticas com o objetivo de fortalecer a estrutura financeira das universidades públicas, mediante repasses indiretos, não tiveram resultados efetivos. A introdução da cobrança de mensalidades nas universidades públicas, a despeito de seu custo político, não conseguiu resolver o problema do financiamento dessas instituições. Por sua vez, o

10. Na Argentina, o crescimento de $96,6 \%$ nas matrículas totais de ensino superior entre 1982 e $199 \mid$ coincide com o período em que houve incremento dos gastos com ensino superior e com a reintrodução do acesso irrestrito às universidades públicas. 
setor privado, financiado com recursos privados mediante o pagamento de mensalidade dos alunos, vem ampliando continuamente, em termos absolutos e relativos, suas matrículas. Em 1981, elas representavam 59\%; em 1994 atingiram 64, 1\% do total das matrículas de ensino superior. De todos os países considerados, é a Colômbia que apresenta, atualmente, a maior participação relativa de matrículas privadas no sistema de ensino superior.

Os problemas que atingiram o ensino superior na Colômbia, no início dos anos 80, além de persistirem, avolumaram-se nesta década. Existe, atualmente, uma forte diferenciação vertical, ou estratificada, no sistema de ensino superior (Lúcio, Serrano, 1993), a qual tende a ser legitimada pelo reconhecimento de que algumas universidades - tanto públicas como privadas - distinguem-se das demais por sua excelência acadêmica.

○ sistema de ensino superior no Chile apresenta outras características. Em dez anos (1980 a 1990), a taxa de crescimento de matrícula de ensino superior ficou em 9,7\%, a menor taxa verificada, para esse período, de todos os países considerados. Entretanto, entre 1991 e 1994, ela cresceu 31, 1\%, o que parece indicar o início de uma nova fase de expansão. No que se refere à participação relativa das matrículas privadas, o período entre 80 e 94 indica crescimento acelerado.

Durante a vigência do regime militar no Chile, houve declínio constante nos gastos públicos para o ensino superior: em 1979, eles representavam I, I\% do PIB; em 1982, imediatamente depois da reforma universitária ( 1980), situavam-se em I\% do PIB, decrescendo abruptamente para 0,6\% do PIB em 1986 (Brunner, 1986). O declínio do financiamento público não significou, contudo, ausência de controle, por parte do Estado, da expansão do setor privado até quase o final do regime militar. A contração dos gastos governamentais para o ensino superior, na realidade, derivou de duas lógicas que prevaleceram em diferentes fases do regime autoritário chileno. Na primeira fase, em que dominou a componente repressiva, a universidade chilena passou por um processo muito parecido com o da universidade pública da Argentina: a redução do financiamento público era uma estratégia que visava à desmobilização política e à penalização do segmento universitário. Na segunda fase, que se inicia no final dos anos 70, presenciou-se a formulação de um programa de reforma para o ensino superior. Nesse programa, a redução dos aportes fiscais para as universidades fazia parte de reformas estruturais mais amplas que começavam a ser implementadas no país. A reforma educacional de 1980 inscreveu-se nesse quadro (Klein, Sampaio, 1996).

O objetivo da reforma educacional de 1980 no Chile foi sobretudo o de redefinir o papel do Estado em relação aos encargos financeiros referentes ao sistema de ensino superior. Uma das medidas da reforma foi a introdução da cobrança de anuidades estudantis nas instituições públicas. Desde a reforma, o governo começou a operar duas linhas de financiamento: aportes fiscais diretos, distribuídos entre as universidades antigas, tanto públicas como privadas, e entre as novas instituições, só públicas, de acordo 
com percentuais fixos estabelecidos por lei; e aportes fiscais indiretos, outorgados pelo Estado às universidades tradicionais, aos institutos profissionais e às novas universidades privadas que tivessem, entre seus alunos matriculados, estudantes entre os 27.500 mais bem colocados no exame de ingresso (Brunner, 1993). Tal sistema de financiamento ainda está em vigor. De um lado, pelo menos teoricamente, tem contribuído para diversificar as fontes de recursos para o segmento do sistema de ensino superior com aporte fiscal, instaurando mecanismos de financiamento múltiplos. De outro, parece favorecer a expansão de um novo setor privado, que diferentemente das universidades católicas tradicionais, independe de recursos públicos e atende candidatos menos qualificados academicamente.

\section{SETOR PRIVADO, MERCADO E ESTADO NA AMÉRICA LATINA}

A trajetória do ensino superior privado e de sua interação com o setor público em cinco países da América Latina - Argentina, Brasil, Chile, Colômbia e México - pode ser mais bem delineada com base nos dados apresentados.

A característica mais evidente é o crescimento do setor privado nos cinco países, tornando-se predominante em três: Brasil, Chile e Colômbia. $\bigcirc$ timing da expansão do setor privado em cada país também foi diferente. Mais precoce no Brasil e na Colômbia, intensificou-se no México, Argentina e Chile nas décadas de 80 e de 90, período em que se verifica diminuição no ritmo de crescimento das matrículas totais de ensino superior. Nestes três países, a expansão do setor privado parece resultar antes das dificuldades do setor público para manter seu ritmo de absorção da demanda de ensino superior do que de uma explosão extemporânea desta demanda.

A segunda tendência comum aos diferentes sistemas nacionais é a especificidade do segmento privado confessional. Sua emergência e consolidação ocorreram de forma independente, ou apenas parcialmente dependente, dos fatores de mercado, verificando-se tanto antes como durante o período de crescimento das matrículas de ensino superior. $\bigcirc$ fato de as universidades católicas tenderem a se organizar de forma semelhante às universidades públicas conferiu-lhes uma função paralela nos sistemas de ensino superior nos quais o setor público manteve-se mais restrito, preservando sua qualidade. A diferença entre esses dois segmentos reside antes na oposição laico/confessional do que na oposição setor público/setor privado. Em maior ou menor grau, o segmento confessional recebeu recursos oficiais como se fosse público.

A terceira tendência diz respeito às diferentes formas de interação entre setores público e privado no atendimento à demanda de massa.

A primeira alternativa é representada pela Argentina e pelo México. Nesses dois países, o Estado procurou suprir a demanda de massa adotando políticas de ingresso irrestrito, ou quase, às universidades públicas. Com isso, foi o setor público que cumpriu a 
função de mass sector (Geiger, 1986). A adoção do ingresso irrestrito abriu as portas das universidades públicas, agigantando-as, e prejudicou o desenvolvimento da pesquisa e da qualificação do pessoal docente.

Em contextos em que o setor público assumiu o atendimento da demanda de massa, o setor privado tendeu a estabelecer uma relação complementar com o primeiro. Criaram-se, assim, instituições privadas mais seletivas que, mesmo não se desenvolvendo como grandes centros de pesquisa, procuraram, ao menos, oferecer um ensino de qualidade superior àquele oferecido pelas universidades públicas de massa.

A segunda opção parece ter sido a adotada pelo Chile e Brasil. Procurou-se preservar, e até aprimorar, a excelência do setor público mediante a implementação de políticas de estímulo às atividades de pesquisa e à qualificação docente. Nessa alternativa, mantevese o ingresso restrito às universidades públicas. Mesmo ampliando, em alguns períodos, o número de vagas oferecidas, o setor público foi incapaz de absorver a demanda de massa, que foi represada. Essa demanda represada criou condições favoráveis ao desenvolvimento da iniciativa privada.

A inibição, ou mesmo o controle, da expansão do setor privado, simultaneamente à preservação de um ensino público seletivo, tal como ocorreu no Chile, só se verificou em um contexto no qual o Estado pretendeu e foi capaz de manter um controle muito rígido sobre o sistema de ensino em seu conjunto e mostrou-se eficaz no enfrentamento da frustração da demanda reprimida. No Brasil, ao contrário, onde a contenção do sistema de ensino superior não ocorreu, a expansão do setor privado foi explosiva.

Quando a opção foi pela manutenção do caráter seletivo do ensino público, as instituições privadas de elite tenderam a ocupar um nicho pequeno no sistema, salvo quando foram também subsidiadas pelo Estado. Nesse contexto, o segmento privado de elite cumpre funções similares às do setor público e complementa o setor privado de massa.

A Colômbia constitui um caso singular. Nesse país, constata-se que a ausência de tomada de decisão sobre a vocação do setor público levou à fragmentação do sistema de ensino superior em instituições públicas e privadas de diferentes padrões. Não se firmou nem um setor público seletivo e de qualidade nem um setor público capaz de absorver a demanda de massa. Instituições de ambos os setores - o público e o privado - cumprem todas essas funções. A crise de financiamento do ensino público colombiano contribui, ademais, para a deterioração da qualidade desse setor (Patrinos, 1990).

Teoricamente, seria possível uma terceira alternativa. Contudo, ela não se realizou plenamente em nenhum dos países considerados. A opção seria pela diversificação do setor público, preservando algumas universidades de elite, voltadas para a associação entre pesquisa e formação de pessoal qualificado e criando outras, mais flexíveis, mais técnicas, ou mais voltadas para o ensino, que pudessem atender à demanda de massa. Os cerca de 100 institutos tecnológicos públicos, no México, que chegaram a absorver em torno de 
200 mil estudantes, perfazendo quase 20\% do total de matrículas em nível superior " em 1993, constituem tentativas, por parte do setor público, de buscar maior diversificação na oferta de ensino superior.

Cabe notar que, no México, dada a reconhecida deterioração de pelo menos parte do setor público e sua dificuldade de incorporar a pesquisa, vêm sendo criadas, mais recentemente e de forma associada às universidades, instituições voltadas à pesquisa. Essas instituições atuam de modo semelhante à pós-graduação.

Embora existam iniciativas isoladas como essas, a tendência geral foi a de uma diversificação muito pequena no atendimento público de ensino superior. $\bigcirc$ Estado tendeu a seguir duas alternativas: a manutenção de instituiç̧̃es seletivas ou a absorção da demanda de massa, enquanto o setor privado se diversificou conforme as aberturas do mercado.

Os problemas que se apresentam para as políticas públicas nos anos 90 provavelmente só poderão ser resolvidos se forem repensadas as alternativas do ensino superior público e reorganizadas as relações entre setor público e privado no sentido de superarem a oposição entre qualidade e quantidade que hoje são constitutivas da heterogeneidade dos sistemas de ensino superior nos países analisados.

\section{O PÚBLICO E O PRIVADO NO DEBATE CONTEMPORÂNEO}

Os anos 80 constituem também um divisor de águas na interação entre Estado e sistemas de ensino superior. É nesse período que se verificam algumas tendências de transformação dessa relação. O fenômeno não é específico da América Latina, mas ocorrente e contemporâneo em diferentes países e continentes (Levy, 1986; Still, 1991 ; Mahony, 1994; Neave, Van Vught, 1994).

O estabelecimento de um setor confessional, ocorrido anteriormente, havia significado a quebra do monopólio do Estado sobre o sistema de ensino superior. A existência, lado a lado, de setores público/laico e privado/confessional, contudo, não implicou nenhuma alteração na interação Estado e sistema de ensino superior. No limite, a relação que as instituições católicas lograram estabelecer com o Estado foi de dependência financeira, inclusive, como ocorreu em maior grau no Chile, mas também no Brasil e na Colômbia. $\bigcirc$ mesmo modelo pode ser estendido à interação entre Estado e instituições privadas laicas de elite.

Desde a segunda metade dos anos 80, entretanto, dois fenômenos vêm confluindo para alterar as relações tradicionais que os Estados dos países latino-americanos sempre mantiveram com os seus respectivos sistemas de ensino superior: de um lado, a crise de financiamento que atinge os Estados desses países, repercutindo no fluxo de recursos destinados ao setor público; de outro, a consolidação de um mass private sector.

II. Também no setor público, foram criadas, em 1990, três universidades tecnológicas; juntas absorviam menos de mil alunos (Kent, 1995). 
É nesse contexto que se desenvolve o debate contemporâneo sobre os sistemas de ensino superior na América Latina. No debate, o termo privatização tem sido usado para designar experiências muito distintas: desde o aumento da participação relativa das matrículas privadas, sobretudo nos países com uma larga tradição no atendimento público da demanda de ensino superior (Argentina e México), a introdução da cobrança de taxas de matrículas e de anuidades em universidades públicas (Chile no início dos anos 80 e mais recentemente na Colômbia), e até as propostas de controle de custos no setor público de ensino superior, bem como as diferentes iniciativas de avaliação institucional. A privatização transforma-se, assim, em um esquema explicativo presente tanto em análises acadêmicas que se propõem a traçar a trajetória do ensino superior privado na América Latina, como no debate político que envolve a formulação das políticas para o ensino superior nesses países. $\bigcirc$ debate, na maior parte das vezes, tende a ser reduzido à polarização mercado versus Estado; em torno dessa polarização, alinham-se diversos sujeitos que participam do sistema de ensino superior: os principais são os policy makers, os experts, os docentes organizados, os estudantes, os proprietários dos estabelecimentos privados, várias associações que reúnem representantes de instituições públicas e privadas.

Em geral, segmentos do ensino superior público, representados por suas entidades e sindicatos, advogam a manutenção do financiamento estatal, e se possível, o incremento de recursos ao ensino superior público. Atribuem, ainda, ao Estado, o controle da qualidade e da expansão do setor privado, resistindo veementemente a qualquer possibilidade de políticas de incentivo financeiro às instituições privadas de ensino superior. Por sua vez, segmentos ligados ao setor privado pleiteiam, junto ao Estado e seus representantes, menor rigidez nas normas que regulamentam a expansão do ensino privado, pois segundo o entendimento desse grupo, cabe ao mercado, e não ao Estado, o controle desse setor de ensino superior. A exceção se verifica, como pode ser observado no Brasil, no caso da pesquisa. Algumas instituições particulares têm-se organizado e procurado obter, junto aos órgãos de fomento à pesquisa e à pós-graduação, recursos destinados a essa finalidade. De acordo com os representantes da iniciativa privada, os recursos públicos para a pesquisa são fundamentais para a promoção da qualidade do ensino superior particular. Na Colômbia, em especial, as posições estão muito polarizadas. Conforme observam Lúcio e Serrano (1993), enquanto alguns segmentos do sistema de ensino superior atribuem ao Estado o papel de controlar a qualidade do sistema e desenvolvê-lo, outros advogam a necessidade de maior independência para o sistema de ensino superior em relação ao Estado, com instituições livres para decidirem que modalidades de programas e cursos irão desenvolver, ou seja, um sistema mais plenamente voltado para o mercado ${ }^{12}$.

12. Essa polarização, de acordo com Lúcio e Serrano (1993), inscreve-se em um quadro de ambigüidade entre os princípios gerais da Carta Constitucional de 1991 sobre o papel do Estado na educação em todos os níveis e a política mais recente do governo visando à abertura da economia. 
Para se entender o conflito político subjacente, devem-se considerar os instrumentos que, tradicionalmente, estiveram à disposição do Estado para controlar o desenvolvimento dos sistemas de ensino superior. Nos países estudados foram basicamente dois: o normativo, por meio de legislação, e o financeiro. $O$ primeiro aplica-se a todo o sistema de ensino superior; o segundo, o financeiro, com exceção do Chile, tendeu a se restringir ao ensino superior público.

No Brasil, em especial, a tendência sempre foi o excesso de normas legais, o que muitas vezes mais engessou do que promoveu o desenvolvimento da qualidade do ensino superior, tanto público quanto privado. Já o controle da distribuição do montante dos recursos financeiros, que tem-se mostrado mais eficaz, não se aplica ao setor privado em seu conjunto.

Nos setores públicos ou nos privados que apresentam dimensões reduzidas e são mais seletivos, a eficácia do controle de qualidade dependeu de fator exógeno à ação governamental: a comunidade acadêmica, ou oligarquia acadêmica, na designação de Clark (1983). É a comunidade acadêmica que tem, tradicionalmente, assegurado os mecanismos internos de promoção da qualidade; esses mecanismos completam a ação do Estado e são indispensáveis para o ajuste do sistema em seu conjunto.

Retomando a questão levantada no início deste trabalho, devemos reafirmar que, no setor privado de atendimento à demanda de massa, a ação da autoridade acadêmica é praticamente neutralizada. Em seu lugar, surge a figura das mantenedoras - as proprietárias dos estabelecimentos privados de ensino superior. A lógica que orienta a oferta de ensino superior nesses estabelecimentos se prende antes às exigências do mercado. A orientação para o mercado, associada à perda de autonomia (e mesmo de influência) do corpo acadêmico no setor privado empresarial, soa como uma ameaça ao próprio ethos universitário. No setor privado de atendimento de massa, normalmente a competição entre os estabelecimentos não se estabelece nem para valorizar a preparação e a qualificação do corpo docente nem para promover a qualidade do ensino.

Em suma, o que tem ocorrido nos diferentes países é uma impossibilidade de orientar, com os instrumentos de controle à disposição do Estado, a qualidade do ensino oferecido. Essa é uma das principais razões pelas quais, nesses países, os Estados vêm adotando novos instrumentos de controle, não meramente normativos, sobre os respectivos sistemas de ensino superior. Um dos instrumentos é a avaliação de desempenho das instituições, a qual se tornou foco de intenso debate nos últimos anos. A introdução de mecanismos de avaliação institucional estabelece uma nova forma de controle do Estado sobre o conjunto do sistema alternando as relações tradicionalmente existentes. Em relação ao setor público, a avaliação institucional cumpre, além de controlar a qualidade, a função de orientar a política de financiamento das instituições que compõem o setor, aumentando o controle governamental sobre ele. No tocante ao setor privado de atendimento de massa, a avaliação institucional visa, sobretudo, promover o controle 
de qualidade, eliminando o excesso de autonomia que caracteriza as instituições desse setor.

A modificação das relações entre poder público e sistema de ensino superior encontra forte oposição, esbarrando em interesses corporativos solidamente entrincheirados nos sistemas nacionais. Contudo, o interesse por parte dos Estados na institucionalização da avaliação constitui resposta necessária às profundas transformações pelas quais passam os sistemas de ensino superior latino-americanos.

\section{REFERÊNCIAS BIBLIOGRÁFICAS}

BALÁN, J. Governance and finance of national universities in Argentina: current proposals for change. Higher Education, v. 25, n. I, p. 45-60, 1993.

La Universidad privada en América Latina. In: SEMINÁRIO INTERNACIONAL SOBRE EDUCACIÓN SUPERIOR. Desafios de la educación superior. La Paz: Unidad de Análisis de Politicas Sociales, 1993a.

BARON, A. Economía política de la educación superior: reflexiones sobre la experiencia argentina. Educación Superior y Sociedad, v. 7, n. 2, p. 23-50, 1996.

BRUNNER, J. J. Chile's higher education: between market and state. Higher Education, v. 25, n. I, p. 35-44, 1993.

Informe sobre la educación superior en Chile. Santiago: Flacso, 1986. (mimeo)

CLARK, B. The higher education system. Los Angeles: University of California Press, 1983.

COX, C. Higher education policies in Chile in the 90's. Higher Education Policy, v. 9, n. I, p. 29-43, 1996.

CUNHA, L. A. Universidade: ensino público ou liberdade de ensino? In: BORI, C. (org.). Ciência e Cultura, v. 37, n. 7, p. 9.220-8, 1985. (Suplemento universidade brasileira: organização e problemas.)

A Universidade crítica. 2. ed. Rio de Janeiro: Francisco Alves, 1989.

DELLA PAOLERA, G. D. El Mercado universitario en la Argentina y la universidad de gestion privada. In: SEMINÁRIO INTERNACIONAL SOBRE EDUCACIÓN SUPERIOR. Desafios de la Educación Superior. La Paz: Unidad de Análisis de Politicas Sociales, 1993.

DURHAM, E. R. Uma política para o ensino superior. São Paulo, 1993. (Documento de Trabalho Nupes 2/93)

FANELLI, A. M. Las Nuevas universidades del conurbano bonarense: misión demanda externa y construcción de un mercado académico. Buenos Aires, 1997. (Documento Cedes/1 17, Serie Educación Superior) 
FIGUEROA, C. P. Challenges of higher education in Mexico during the nineties. Higher Education Policy, v. 9, n. I, p. 45-54, 1996.

FUENZALIDA, E. F. The Institucionalization of research in Chile's universities. California: Stanford University, s.d. mimeo.

GARCIA, C. G. La Reforma de la educación superior en Venezuela desde una perspectiva comparada. In: CATANI, A. (org.). Congresso Internacional de Políticas de Educação Superior na América Latina no Limiar do Século XXI, Recife, 1997.

GEIGER, R. Private sectors in higher education: structure, funcion and change in eight countries. Ann Arbor: University of Michigan Press, 1986.

KENT, R. Tendencias y problemas en la educación superior en Mexico: los años noventa. Mexico: Departamento de Investigación de Estudios Avanzados del Instituto Politécnico Nacional, 1995 (Documento DIE 4I)

KLEIN, L., SAMPAIO, H. Actores, arenas y temas básicos. In: KENT, R. (org.) Los temas críticos de la educación superior en America Latina: estudos comparativos. Mexico: Flacso, Fondo de Cultura Económica, 1996.

LEMAITRE, M. J. El Consejo Superior de Educación: una experiencia de regulación de instituciones privadas de Educación Superior. Informe de la Educación Superior. Argentina: Colección Foro de la Educación Superior, p. 177-272, 1993.

LEVY, D. Alternative private-public blendy in higher education finance: International patterns. In: LEVY, D. (org.). Private education studies in choice and public policy. Oxford: Oxford University Press, 1986. p. 195-213.

Higher education and state in Latin America: private challenges to public dominance. Chicago, Illinois: University of Chicago Press, 1986a.

Private institutions of higher education. In: CLARK, B., NEAVE, G. (orgs.). The Encyclopedia of higher education. New York: Pergamon Press, 1992, v. 2, p. I I8395.

LÚCIO, R., SERRANO, M. La Educación superior en Colombia: desarrollo, tendencias, políticas estatales. Colombia, 1991. mimeo

The State and higher education in Colombia. Higher Education, v. 25, p.6172, 1993.

MAHONY, D. Government and the universities: the new mutuality in australian higher education; a national case study. Journal of Higher Education, v. 65, p. 123-46, 1994.

MARQUIS, C. El Gobierno nacionaly las universidades argentinas. Buenos Aires, 1992. mimeo 
MARTINS, C. B. De la evaluación a las reformas en el sistema universitario argentino. Educación Superior y Sociedad, v. 7, n. 2, p. 13-22, 1996.

Novo ensino superior privado no Brasil 1964-1980. In: MARTINS, C. B. (org.). O Ensino superior brasileiro: transformações e perspectivas. São Paulo: Brasiliense, 1989, p. II-48.

MATTOS, P. L. C. L. As Universidades e o governo federal. Recife: Universidade Federal de Pernambuco, 1983.

NEAVE, G., VAN VUGHT, F. (orgs.). The Change relationships between gouvernement and higher education in western Europe. Oxford: Pergamon Press, 1994.

PATRINOS, H. A. The Privatization of higher education in Colombia: effects on quality and equity. Higher Education, v. 20, p. 161-73, 1990.

SCHWARTZMAN, J. Uma folha de pagamento das universidades federais. São Paulo, 1993. (Documento de Trabalho Nupes 2/93)

SCHWARTZMAN, S. Brazil. In: CLARK, B., NEAVE, G. (org.). The Encyclopedia of higher education. Oxford: Pergamon Press, 1992, p. 82-92.

SCHWARTZMAN, S., BOMENY, M. H. B., RIBEIRO, V. M. C. (orgs.). Tempos de Capanema. São Paulo: Edusp; Paz e Terra, 1984. Parte III: Tempo de Reforma. p. 173-230.

STILL, J. Private higher education: the Philippines as a prototype. Higher Education, v. 21 , p. 189-206, 1991. 
